\title{
Revitalisasi Kesadaran Berbangsa Melalui Pendidikan Berbasis Multikultural
}

\author{
Debi Setiawati \\ Program Studi Pendidikan Sejarah dan Sosiologi IKIP Budi Utomo Malang \\ Jalan Citandui 46 Malang \\ bungajeruk@yahoo.com,
}

\begin{abstract}
The aim of this research is to study the role and how to develop of multikultural education in growing awareness nation for college students course history and sociology education IKIP Budi Utomo Malang. Research methods used in the form of qualitative research phenomenological approach that emphasizes understanding the meaning and the various events and human interaction. The research is found an awareness of the students education country history and sociology IKIP Budi Utomo Malang unfortunate, However it is important to develop through education multikultural marriages packed in academic and non academic. The resistance found in developing multikultural education in internal and eksternal. That is internal from students who still have the character of a toughregional blend and adapt, While esternally of organization provides space for accommodating the aspirations of students to administer activities on campus and outside.
\end{abstract}

Keywords : Character Nationality, Multikultural Education.

Isu krisis sosial dan budaya menjadi salah satu tantangan bangsa Indonesia di Era Globalisasi. Masing-masing kelompok ingin menunjukkan superioritasnya terhadap kelompok yang lain. Mereka tidak lagi mengenal batas - batas keruangan maupun sekat sekat yang ada dalam masyarakat, sehingga kelompok mayoritas bebas untuk mengintervensi kelompok minoritas. Identitas yang dibawa masing - masing individu sering kali menjadi pemicu munculnya konflik sosial. Indonesia sebagai bangsa yang bersifat majemuk yaitu memiliki keanekaragaman budaya, suku, agama,ras, etnis, status sosial, bahasa, dsb sangat mudah berpeluang munculnya konflik Sosial.Hal itu tentunya dapat berpengaruh terjadinya disintegrasi bangsa. Secara Historis konsep keanekaragaman yang ada dalam bangsa Indonesia telah disadari oleh para leluhur kita yang tertuang dalam kitab Sutasoma yaitu : Bhineka Tunggal Ika Tan Hana Mangga
Margawa, artinya berbeda-beda tetapi tetap satu jua. Dari semboyan Bhineka Tunggal Ika tersebut lahirlah Negara Kesatuan Republik Indonesia (NKRI).

Masuknya budaya barat yang bersifat western, sedikit banyak mampu mengintervensi budaya asli yang bersifat ketimuran, sehingga nilai- nilai budaya Indonesia mengalami pergeseran bahkan hilang. Generasi muda kita kadang tidak mampu untuk menfilter terhadap pengaruh budaya luar. Mereka hanya mengikuti trend, agar diterima dalam pergaulannya tanpa memikirkan akan dampaknya. Kondisi ini akan menyebabkan munculnya penyakit sosial seperti: Tawuran, Free Seks, Narkoba, Kriminalitas, Pornografi dan Pornoaksi, Terorisme. Penyakit - penyakit sosial inilah yang dapat menghancurkan masa depan bangsa kita.

Fenomena dalam konflik sosial budaya yang terjadi dalam beberapa waktu yang lalu 
antara lain konflik Poso, Kerusuhan di Sampit antara Orang Madura dengan Dayak, Konflik di Aceh anatara GAM dengan penduduk local dengan pemerintah, Tawuran antar pelajar di Jakarta, Tawuran antar mahasiswa UKI di Jakarta, Tawuran antar mahasiswa di UNHAS, Tawuran antar mahasiswa Nusa Tenggara Timur di Universitas PGRI Kanjuruhan Malang, Penjarahan geng motor di Bandung, Pengeboman tempat - tempat ibadah di Ambon, Solo, Yogyakarta dan Situbondo, Pengeboman di Bali dan di Jakarta yang dilakukan para teroris, Tragedi kemanusiaan dan antaragama di Sambas dan Banyuwangi. Peristiwa tersebut menjadi bukti dan cerminan bahwa pondasi Negara Kesatuan Republik Indonesia (NKRI) mengalami krisis kebangsaan yang berbasis Multikulturalisme (Mahfud, 2006:9). Untuk itu perlu dibangun karakter kebangsaan berbasis Multikulturalisme dalam mental generasi muda saat ini, khususnya dalam bidang pendidikan.

Pendidikan memiliki kedudukan yang strategis dalam mentransmisi nilai - nilai budaya, selain keluarga dan masyarakat. Melalui peran sekolah dan guru diharapkan dapat mentarnsformasi nilai -nilai yang bersifat akademik ke dalam nilai-nilai sosial dan budaya, sehingga akan ada kesinambungan antara pengetahuan yang di terima di sekolah dapat diterapkan dalam realitas kehidupan sehari - hari. Di Dalam pendidikan, Kesadaran berbangsa dan bernegara yang berbasis Multikulturalisme dapat dikembangkan melalui pendidikan multikultural.

Pendidikan multikultural merupakan pendidikan yang menekankan adanya toleransi dalam keanekaragaman budaya. Perbedaan budaya yang dimiliki oleh masing - masing kelompok tidak menjadi penghalang, akan tetapi dapat saling melengkapi terwujudnya khasanah budaya Nasional Indonesia. Pendidikan multikultural juga akan mengarahkan peserta didiknya untuk berpandangan toleran terhadap realitas masyarakat yang beragam baik dilihat dari budaya, suku, agama, etnis dan ras. Pandangan tersebut dapat diartikan bahwa masing masing individu atau kelompok dapat menekan sikap ekslusive dalam masyarakat, tetapi sebaliknya mereka dapat saling mengenal dan mempelajari perbedaan yang ada demi terwujudnya kebersamaan dalam satu bangsa (nation) .

Pada masa era globalisasi saat ini, bangsa Indonesia mengalami krisis kebangsaan yang berbasis multikulturalisme. Generasi muda yang merupakan harapan bangsa banyak yang terjerumus pada krisis sosial dan budaya, bahkan kehilangan jati diri dan identitas bangsanya. Pancasila sebagai pandangan hidup bangsa, hanya dipandang sebatas simbolik saja tanpa mampu diinternalisasi dalam jiwanya, Semangat patriotisme dan Nasionalisme hanya dianggapa slogan yang tidak memiliki arti apapun, Bahkan semboyan Bhineka Tunggal Ika, Tan Hana Mana Manggarwa, sebagai tonggak lahirnya Negara Kesatuan Republik Indonesia juga tidak memiliki makna apapun dalam kehidupan generasi muda kita.Unsur - unsure pemersatu bangsa yang menjadi identitas bersama tidak lagi dianggap memiliki makna bagi perkembangan dan kemajuan bangsa, justru nilai Sains dan Teknologi yang lebih dikembangkan dalam menghadapi era globalisasi. Generasi muda sebagai motor penggerak perubahan bangsa, seharusnya dibekali nilai - nilai karakter kebangsaan, tetapi sebaliknya lebih dibekali pada perkembangan ilmu pengetahuan dan teknologi.

Pendidikan memiliki peranan yang penting dalam memanusiakan manusia menjadi lebih beradab. Melalui pendidikan dapat tercipta transfer knowledge dan budaya yang dapat membentuk karakter seseorang. Untuk itu sekolah sebagai lembaga pendidikan 
formal seharusnya dapat mewadahi berbagai perbedaan karakter yang dimiliki oleh peserta didiknya. Kebijakan yang diterapkan di sekolah juga harus dapat mengakomodir berbagai kepentingan yang berbeda. Pola kepemimpinan di sekolah juga harus berbasis multikultural, agar dapat meredam berbagai konflik baik secara internal maupun eksternal.

Sependapat dengan itu Menurut Suryaman (2010) bahwa pendidikan multikultural dapat digunakan sebagai salah satu alternative penyelesaian konflik SARA (Suku, Agama, Ras dan Antar Golongan) yang menjadi isu nasional dewasa ini. Pendidikan Multikultural lebih menekankan pada keragaman latar belakang yang dimiliki peserta didik seperti Etnis, Ras, Suku, Agama, Gender Status Sosial, Kemampuan Intelektual, Umur dan Budaya. Oleh karena itu tujuan yang ingin dicapai tidak hanya sebatas pada kemampuan secara kognitif saja, Akan tetapi juga bersifat afektif dan psikomotorik. Di dalam diri peserta didik diharapkan dapat tumbuh kesadaran akan nilai - nilai humanis, pluralis dan demokratis agar tidak terjadi gegar budaya (culture shock). Untuk itu seorang guru yang professional tidak hanya dituntut dapat menyampaikan materi dengan baik, akan tetapi juga harus dapat menanamkan nilai-nilai demokrasi, pluralism dan humanism.

Sedangkan Buchori (2007) mengatakan bahwa Pendidikan merupakan sarana yang paling tepat untuk mengembangkan kesadaran berbangsa yang berbasis multikulturalisme. Pendidikan multikultural merupakan upaya kolektif suatu masyarakat majemuk. Untuk mengelola berbagai prasangka sosial yang ada dengan cara-cara yang baik, tujuannya adalah untuk menciptakan hubungan lebih selaras dan kreatif diantara berbagai golongan. Melalui pendidikan multikultural, siswa yang datang dari berbagai latar belakang budaya untuk saling mengenal cara hidup mereka, adat istiadat, kekuasaaan untuk memahami aspirasiaspirasi mereka, serta untuk mengakui dan menghormati bahawa tiap golongan memiliki hak menyatakan diri menurut cara hidupnya.

Menurut Tilaar (2002) Pendidikan Multikultural sangat penting diharapkan guna meminimalisasi dan mencegah terjadinya konflik di beberapa daerah. Mellaui pendidikan berbasis multikultural, sikap dan pemikiran peserta didik akan lebih terbuka untuk memahami dan menghargai keberagaman. Dengan pengembangan model pendidikan berbasis multikultural diharapkan mampu menjadi salah satu metode efektif meredam konflik. Selain itu pendidikan multikultural bisa menanamkan sekaligus mengubah pemikiran peserta didik untuk benar-benar tulus menghargai keberagaman etnis, agama,ras,dan anatar golongan.

Buchori (2007) menyatakan bahwa pendidikan multikultural diselenggarakan sebagai sarana melahirkan proses intrgrasi bangsa yang sehat dan melahirkan identitas bangsa yang sesuai dengan perkembangan zaman. Masyarakat Indonesia yang multikultural rentan dengan konflik antar kelompok. Pendidikan multikultural relevan untuk membangun nasionalisme ke Indonesiaan dalam menghadapai tantangan global, karena memiliki nilai inti dalam perspektif lokal maupun global yaitu :

1. Ketakwaan terhadap Tuhan Yang Maha Esa

2. Tanggung jawab terhadap Negara kesatuan

3. Menjunjung tinggi supremasi hukum dan penghargaan martabat manusia dan hak asasi yang universal

4. Penghargaan, pengakuan dan penerimaan keragaman budaya

Pendidikan multikultural mempunyai tujuan yang selaras dengan upaya membangun nasionalisme ke-Indonesiaan dalam menghadapi tantangan global (Hartono, dkk, 2011: 33-34). Pendidikan Multikultural tidak hanya bertujuan agar supaya generasi muda mudah memahami meteri pelajaran yang diberikan, akan tetapi juga dapat 
meningkatkan kesadaran sekolah berperilaku humanis, pluralis dan demokratis. Hal ini merupakan bagian dari proses seabai sebuah strategi dan konsep pendidikan berbasis keragaman budaya, maka pendidikan multikultur memaparkan proses perkembangan kultur yaitu in-kulturasi dan Sosialisasi (Yaqin, 2005:13)

Kesadaran untuk berperilaku humanis, pluralis dan demokrasi sebagai bagian dari tujuan pendidikan multikultural tidak akan dapat terwujud tanpa ketersediaan media kultur yang mendampinginya. Salah satu diantaranya adalah melalui media pendidikan sejarah. Kajian - kajian Historis atas problem kultur bangsa saat ini sangat urgen untuk dilakukan penelitian historis akan memberikan lapangan kajian yang luas mengenai komunikasi lintas budaya (Cross Cultur Communication), antara satu komunitas dengan komunitas yang lain menjadi dasar bagi proses integrasi di kalangan masyarakat Indonesia (Sulistiyono, 2008:45)

Kesadarandan keragaman budaya harus diberikan dalam proses pendidikan formal di tingkat LPTK (lembaga Pendidikan Tenaga Kependidikan). Pendidikan multikultural dapat dilakukan secara terintegrasi dengan kelompok mata kuliah lain seperti : MKPK (Mata Kuliah Pengembangan Kepribadian),MKK (mata Kuliah Keilmuan dan Ketrampilan), MBB (Mata Kuliah Berkehidupan Bermasyarakat). Oleh karena itu cara penguatan pendidikan multikultural di LPTK (lembaga Pendidikan Tenaga Kependidikan) dapat dilakukan dengan cara :

1. Konsistensi pengambil kebijakan di LPTK (lembaga Pendidikan Tenaga Kependidikan) yang memandang bahwa pendidikan multikultur wajib dimasukkan ke dalam kurikulum program studi

2. Kontribusi staf pengajar pendidikan sejarah dalam penguatan materi pendidikan multikultur di LPTK (lembaga Pendidikan Tenaga Kependidikan) melalui penyampaian materi yang tidak bersifat Verbalistis. (Soebijantoro, dkk, 2011, hal 20-24)

Pendidikan multikultural seyogyanya memfasilitasi proses belajar mengajar yang mengubah perspektif monokultural yang esensial, penuh prasangka dan diskriminatif ke perspektif multikulturalis yang menghargai keragaman dan perbedaan, toleran dan sikap terbuka (inklusif). Perubahan paradigma semacam ini menuntut transformasi yang tidak hanya terbatas pada dimensi kognitif lebih dari itu juga menuntut perubahan pada dimensi lainnya, yaitu : afektif dan psikomotorik (Mahfud, 2006:12).

Oleh karena itu penelitian ini bertujuan untuk mengkaji Peranan pendidikan multikultural dan cara mengembankannya dalam meningkatkan kesadaran berbangsa dan bernegara mahasiswa pendidikan sejarah dan sosiologi IKIP Budi Utomo Malang, Serta Memaparkan hambatan yang dihadapi dalam mengembangkan pendidikan multikultural untuk meningkatkan kesadaran berbangsa dan bernegara mahasiswa pendidikan sejarah dan sosiologi IKIP Budi Utomo Malang.

\section{METODE}

Penelitian ini menggunakan pendekatan fenomenologi, yang menekankan pada pemahaman makna dari berbagai peristiwa dan interaksi manusia di dalam situasi yang khusus, sehingga setiap peristiwa harus dilihat dari beragam perspektif dari orang - orang yang terlibat di dalamnya, baik secara pasif maupun aktif, agar dapat dibentuk simpulan yang bersifat multiperspektif yang memiliki intersubyektif.

Berdasarkan masalah yang diajukan dalam penelitian ini, maka jenis penelitian menggunakan kualitatif deskripsi yang mampu menguraikan dan memaparkan berbagai informasi dari realitas masyarakat yang 
memiliki berbagai makna. Strategi yang digunakan adalah studi kasus, yang memiliki lokasi dan periode studi tertentu yang memiliki karakteristik khusus atau unik, sealanjutnya akan dianalisis dan ditarik simpulan dari hasil pengamatan yang ada di lapangan, maka penelitian ini merupakan studi kasus tunggal. Sedangkan jenis strategi penelitiannya kasus ini disebut studi kasus terpancang ( embeded case study research), sebab permasalahan dan fokus penelitian sudah dietentukan dalam proposal.

Penelitian ini dilaksanakan di Program Studi Pendidikan Sejarah dan Sosiologi, IKIP Budi Utomo Malang, yang mayoritas mahasiswanya memiliki keanekaragaman yang tinggi dilihat dari aspek budaya, agama, pendidikan, kondisi sosial dan ekonomi. Penelitian ini dilaksanakan selama enam bulan yaitu dimulai bulan Juli sampai dengan bulan Desember.

Sumber data yang digunakan dalam penelitian ini adalah data primer dan sekunder. Untuk data primer berupa kata-kata dan tindakan orang yang diamati atau diwawancarai. Sedangkan data sekunder berupa foto dan dokumen- dokumen yang relevan dengan tujuan penelitian ini

Data yang dikumpulkan dalam penleitian ini merupakan data kualitatif yang berupa informasi dan realitas yang ada di kampus IKIP Budi Utomo Malang, Khususnya kegiatan akademik maupun non akademik mahasiswa program studi endidikan sejarah dan Sosiologi. Teknik Pengumpulan data yang digunakan berupa wawancara mendalam ( in dept intervuiewing), Observasi secara langsung, pencatatan dokumen, Serta pengarsipan.

Penelitian ini menggunakan teknik cuplikan ( sampling ) sebagai cara untuk menganalisis informasi yang telah dikumpulkan. Teknik cuplikan ini berkaitan dengan pemilihan dan pembatasan jumlah dan jenis sumber data yang akan digunkan dalam penelitian. ( H. Sutopo, 2007). Cuplikan yang akan digunakan dalam penelitian ini bersifat purposive sampling yaitu dengan melakukan pemilihan dan menyeleksi informan yang dianggap memiliki informasi yang akurat dan kebenarannya dapat dipercaya sebagai sumber data dalam memecahkan permasalahan yang ada. Di samping itu juga digunakan cuplikan waktu atau time sampling untuk menentukan waktu yang tepat dalam melakukan observasi dan wawancara, sehingga situasi dan kondisinya tepat yang mempengaruhi kualitas sumber data yang akan diperoleh.

Untuk menguji keakuratan sumber data dilakukan dengan cara trianggulasi data atau sumber yaitu mengumpulkan data sejenis dari beberapa sumber data yang berbeda, sehingga validitas data dapat diuji kebenarannya tidak hanya berasal dari 1 sumber data. Di samping itu juga menggunakan trianggulasi metode atau teknik pengumpulan data yang berbeda seperti wawancara dengan observasi. Trianggulasi metode digunakan untuk cross check dari trianggulasi data ( sumber).

Untuk mengambil kesimpulan dalam penelitian ini menggunakan teknik analisis data kualitatatif yang bersifat induktif yaitu pengambilan kesimpulan didasarkan pada seluruh informasi yang diperoleh di lapangan. Data yang telah ditemukan dan dikumpulkan di lapangan dijadikan sebagai bahan atau dasar pemahaman dalam menyusun kesimpulan. Proses analisis ini dilakukan di lapangan bersamaan dengan proses pengumpulan data, yang dilakukan secara interaktif yaitu dengan membandingkan kesamaan dan ketidaksamaan dari masing - masing sumber data, sehingga setiap data akan selalu dikomparasikan dalam setiap kelompoknya yang disesuaikan dengan tujuan penelitian. Untuk pemantapan dan pendalaman data dilakukan analisis yang bersifat siklus sebagai cara untuk verifikasi data. Proses siklus dilakukan mulai dari awal pelaksanaan pengumpulan data sampai dengan proses 
perumusan kesimpulan. Di dalam proses penarikan kesimpulan dilakukan melalui 3 tahapan yaitu : reduksi data, sajian data dan penarikan simpulan atau verifikasi yang dilakukaan secara siklus.

\section{HASIL}

1. Kondisi Sosial , Budaya dan Ekonomi Mahasiswa Program Studi Pendidikan Sejarah dan Sosiologi

Program Studi Pendidikan Sejarah memiliki mahasiswa yang keanekaragaman sangat tinggi baik dilihat dari latar belakang suku, agama, budaya, bahasa dan kondisi ekonomi. Untuk itu karakter yang dimilikinya juga beragam, yang pada umumnya di bawa dari daerah asal. Proses adaptasi di lingkungan kampus juga membutuhkan waktu yang lama, baik dalam interaksi dengan dosen, antar teman maupun dalam sistem perkuliahan. Pola interaksi yang digunakan mereka sebagian besar masih dipengaruhi budaya asal, sehingga dibutuhkan sikap toleransi yang tinggi agar tidak terjadi gesekan atau konflik.

Sebagian besar mahasiswa prodi pendidikan Sejarah dan Sosiologi berasal dari Nusa Tenggara Timur seperti flores, Ende, Sumba, Manggarai, Pulau Alor, Bajawa, Labuan dan Nagekeo. Di samping itu juga ada yang bersal dari Kalimantan, Sulawesi, Maluku, Papua, Jawa dan Madura.

Kondisi ekonomi sebagian besar mahasiswa Program Studi Pendidikan Sejarah dan Sosiologi dari kelompok menengah ke bawah. Profesi orang tuanya juga beraneka ragam seperti Guru, Pedagang, Petani, Kuli Bangunan, Buruh atau Tenaga Kasar. Oleh karena itu ada beberapa mahasiswa yang berasal dari NTT ( Nusa Tenggara Timur) bekerja sambil kuliah. Mereka mencari pekerjaan sampingan untuk membantu orang tua dalam membiayai kuliah maupun biaya hidup di Malang. Pekerjaan sampingan yang mereka pilih seperti menjaga konter makanan di foodcort, Laundry, penjaga bayi atau anak, pembantu rumah tangga, penjaga konter asesoris di mall, tutor bimbel dan mengajar part time di sekolah dasar. Sedangkan pada libur semester ada sebagian mahasiswa memilih untuk bekerja fuul time selama 2 bulan di Bali maupun Surabaya sebagai pembantu Rumah Tangga maupun pramusaji di restoran.

Kondisi Ekonomi tersebut mempengaruhi juga dalam motivasi mereka mengikuti perkuliahan, ada yang tinggi tetapi ada juga yang rendah. Hal tersebut disebabkan karena mereka tidak dapat membagi waktu dengan baik antara bekerja dan kuliah, sehingga hamper tugas maupun ujian tidak dapat diselesaikan. Selain itu juga ada yang lebih senang bekerja karena telah medapat penghasilan sendiri dan mengesampingkan kuliahnya.

Tempat tinggal mahasiswa di dekat kampus A yang berlokasi di jalan Arjuna yaitu Bareng, Talon, Kasin, Kelud, Bromo. Sedangkan yang ada di sekitar kampus C jalan Cintandui yaitu: Ciwulan, Sanan, Pandean, Karya Timur. Sebagian besar ada yang kontrak rumah bersama dengan teman- teman dari asal daerah yang sama, tetapi ada juga yang indekos di rumah penduduk sekitar. Biaya kos per - kamar sekitar 400 sampai 500 ribu untuk 2 orang. Sedangkan Biaya kontrak rumah sekitar 10 -15 juta disesuaikan dengan jumlah kamarmya. Untuk mahasiswa laki-laki dengan perempuan terpisah tidak boleh jadi satu, sehingga untuk kos maupun kontrakan harus lapor kepada ketua RT atau RW setempat.

Walaupun mereka sebagai pendatang di kota Malang yang memiliki latar belakang budaya berbeda dapat beradaptasi dengan penduduk sekitar kos maupun kontrakan. Penduduk setempat juga mau untuk menerima keberadaan mereka yang memiliki latar belakang budaya yang berbeda dengan budaya Jawa. Bahkan penduduk setempat diuntungkan 
dengan keberadaan mereka antara lain dapat menyewakan rumah, usaha kos, menjual makanan dan minuman, menjual sayuran, membuka took atau warung. Dari hubungan ketergantungan yang saling menguntungkan tersebut, maka tercipta interaksi sosial yang harmonis di lingkungan tempat tinggal mereka. Di samping itu juga pihak Kampus menjalin kerjasama dengan RT maupun RW untuk dapat mengontrol perilaku mereka, agar tidak meresahkan penduduk setempat.

Kerjasama pihak kampus dengan RT dan RW terjalin dengan baik, maka pada acara acara penting di kampus seperti Idul Adha, Buka Puasa Bersama, Halal Bihalal mengundang penduduk setempat agar terjalin silahturahmi yang baik. Acara - acara tersebut dapat dikemas dalam Bakti Sosial, Pembagian hewan Qurban maupun Buka Bersama. Dengan demikian akan tumbuh pecitraan yang positif antara pihak kampus dengan masyarakat.

Hubungan interaksi sosial antar mahasiswa tidak hanya terjalin di rumah kontrakan atau kos-kosan saja. Akan tetapi juga di dalam kegiatan akademik Kampus, antara lain : pada saat perkuliahan di kelas, Diskusi kelopok maupun kelas, Mengerjakan Tugas, Diskusi di Luar Kelas dam keterlibatan bersama dalam kegiatan - kegiatan kampus. Mereka tidak lagi membawa atribut identitas daerah asal masing - masing tetapi mampu berbaur bersama sebagai bagian dari keluarga besar IKIP Budi Utomo Malang.

Walaupun tidak menutup kemungkinan perasaan senasib sepenanggungan hidup di daerah perantaun masih melekat. Akan tetapi hal tersebut tidak menunmbuhkan munculnya sikap primordialisme yang dapat memicu terjadinya disintegrasi bangsa. Perasaan senasib sepenanggungan tersebut muncul dalam situasi - situasi tertentu seperti : kekurangan uang, kekurangan makanan, pijam- meminjam materi perkuliahan, pinjammeminjam tugas kuliah, belajar bersama dalam menemepuh ujian, tukar menukar inforamasi dalam beradaptasi dengan Dosen.

Sebagian besar mahasiswa baik itu lakilaki maupun perempuan setiap hari memasak untuk memenuhi kebutuhan pangan. Hal tersebut di sebabkan karena kiriman uang orang tua yang cukup minim untuk biaya kuliah serta cita rasa yang berbeda dari selera makan daerah asal mereka. Proses masak bisa berkelompok maupun individu disesuaikan dengan kebutuhan. Oleh karena itu dalam memilih teman kos maupun kontrakan di sesuaikan dengan daerah asal. Hal tersebut disebabkan karena mereka mimiliki ikatan persaudaraan yang lebih erat dan telah mengenal karakter masing - masing.

Kegiatan masak bersama di kos maupun rumah kontrakan juga akan menumbuhkan interaksi sosial yang erat, dikarenakan mereka juga harus mengumpulkan uang secara berkelompok baik untuk harian maupun minnguan. Dengan demikian kepercayaan, kerjasama dan tanggung jawab akan menumbuhkan sikap saling menghargai. Kebersihan dan keamanan di rumah kontrakan maupun kos menjadi tanggung jawab bersama penghuninya, sehingga diharapkan masingmasing orang memiliki kepedulian satu dengan yang lain.

Kegiatan akademik di kampus juga melibatkan interaksi sosial antar mahasiswa dalam bekerjasama, berdiskusi, berkomunikasi. Untuk itu dibutuhkan sikap toleransi yang tinggi mengingat latar belakang budaya, agama,suku dan bahasa yang berbeda, agar tidak terjadi konflik SARA (Suku,Agama, Ras dan antar Golongan). Pembagian tugas kelompok di kelas dibuat secara acak agar masing - masing mahasiswa bisa saling mengenal satu dengan yang lain, sehingga bisa mengenal karakter budaya mereka. Di samping itu juga akan menumbuhkan sikap solidaritas dan kerjasama yang dapat memiliki pandangan Multikulturalisme. 
2 Kegiatan Akademik Mahasiswa Program Studi Pendidikan Sejarah dan Sosiologi Di Dalam Kampus

Program Studi Pendidikan Sejarah dan Sosiologi IKIP Budi Utomo Malang memiliki Visi yaitu Menjadi Program Studi Sejarah dan Sosiologi yang unggul, sehat dan berbudi utama pada tahun 2022. Unggul yang dimaksud adalah Program Studi Pendidikan Sejarah dan Sosiologi harus memiliki nilai kompetitif yang tinggi dalam penyelenggaraan tri dharma perguruan tinggi, pengelolaan kelembagaan dan unsur penunjang lainnya. Sehat yang dimaksud harus mampu mandiri, berkelanjutan dan terjamin. Berbudiutamaan dalam visi tersebut adalah memiliki karakter yang khas dan mampu mengemban serta mewujudkan nilai-nilai kemanfaatan, kepedulian, kepatuhan, kepatutan dan keindonesiaan (Borang Akreditasi Program Studi Sejarah dan Sosiologi, 2015).

Kegiatan akademik mahasiswa Program Studi Pendidikan Sejarah dan Sosiologi dilakukan dalam perkuliahan di kelas. Di samping itu juga kegiatan - kegiatan lain yang menunjang akademik mahasiswa seperti pengembangan profesi yaitu Pelatihan Penelitian Tindakan Kelas, Pelatihan Pengembangan Model Pembelajaran dan Pelatihan Kewirausahaan yang di kelola oleh unit Pengembangan Pelatihan Profesi Guru (P3G). Sedangkan untuk menumbuhkan jiwa bela Negara dan membentuk karakter mental yang kuat diadakan kegiatan berupa Jambore yang di kelola oleh unit Kemahasiswaaan dan Alumni.

Untuk menunjang kegiatan akademik mahasiswa di kampus di sediakan sarana fisik yang mendukung seperti : ruang kelas, perpustakaan, Lab Mikroteaching, Lab Bahasa, Ruang Terbuka Yang terdapat Hot Spot area, Cafe, lapangan basket dan Lcd. Sedangkan untuk mempermudah akses akademik telah ada website, group WA, maupun group facebook serta blog yang dimiliki oleh masing - masing dosen. Untuk lebih lengkap sarana dan prasarana penunjang akademik dapat dilihat dalam tabel berikut ini

Kegiatan perkuliahan yang dilaksanakan di dalam kelas diatur selama 3 sampai 4 hari sedangkan sisa waktu lainnya dapat digunakan oleh mahasiswa untuk mengerjakan tugas atau mengikuti kegiatan - kegiatan lainnya yang mendukung potensi akademik mahasiswa seperti Pelatihan, Lokakarya, Seminar dll. Untuk melatih mahasiswa dapat berpikir secara mandiri, maka pada uumnya dosen di Prodi Pendidikan Sejarah dan Sosiologi memberikan tugas diskusi secara berkelompok. Hal tersebut dimaksudkan agar mahasiswa mampu memiliki karakter kerjasama, toleransi, tanggung jawab, demokratis, kritis, disiplin, solidaritas. Bentuk penugasan dapat berupa makalah yang dipresentasikan, analisis jurnal, resensi buku, resume buku, pembuatan peta, pembuatan laporan penelitian mini, pembuatan kliping disertai analisisnya.

Interaksi sosial mahasiswa di dalam kelas bersifat universal, yang mana tidak ada setiap mahasiswa membawa identitas identitas yang bersifat etnisitas. Adapun konflik antar mahasiswa terjadi bukan karena membawa identitas etnisitasnya, akan tetapi gesekan yang muncul dikarenakan masalah masalah yang bukan urgen seperti : tidak dicantumkan namanya di dalam tugas karena tidak mengerjakan, di absen alfa karena tidak masuk, tidak dipinjami tugas, tidak di kasih contekan pada saat ujian. Konflik - konflik yang muncul tersebut dapat diselesaikan secara damai tanpa harus melalui kekuatan fisik atau senjata yang dapat membahayakan nyawa orang lain, serta tidak menyebabkan munculnya disintegrasi bangsa.

Kegiatan mahasiswa di kampus dapat dibedakan menjadi dua yaitu dalam kampus dan luar kampus. Untuk kegiatan di dalam 
kampus bersifat temporal dan terencana sedangkan yang luar kampus isidental dan tidak mengikat. Program Studi Pendidikan sejarah dan Sosiologi dalam melaksanakan kegiatan akademiknya di dukung oleh dosen dosen muda yang kompeten di bidangnya, sehingga mereka dapat mengimbangi interaksinya dengan para mahasiswa, yang sebagian besar usianya tidak begitu jauh.

Interaksi sosial yang terjalin antar mahasiswa dengan dosen tidak hanya terjadi di dalam perkuliahan di kelas, tetapi pada saat di luar kelas mereka dapat konsultasi maupun sharing berkaitan dengan masalah akademik maupun non akademik. Untuk itu di Program Studi Pendidikan Sejarah dan Sosiologi di bentuk Dosen Penasehat Akademik yang memiliki tugas membantu mahasiswa dalam menyelesaikan masalah akademik maupun non akademik. Masing - Masing dosen membimbing kurang lebih 40 mahasiswa yang dipilih secara acak.

Permasalahan akademik yang biasa mereka hadapi berkaitan dengan Indeks Presatasi Kumulatif (IPK) yang rendah, Nilai yang kosong serta cara untuk memperbaiki nilai yang jelek. Sedangkan masalah non akademik berkaitan dengan kesulitan keuangan, konflik dengan orang tua, konflik dengan teman dekat. Masalah - masalah tersebut dapat mempengaruhi motivasi belajar mereka. Oleh karena itu dosen penasehat akademik diharapkan dapat sebagai pebimbing yang mampu memotivasi maupun memberikan solusi terhadap permasalahan-permasalahan yang sedang mereka hadapi.

Interaksi antar mahasiswa di kampus tidak hanya di kelas pada saat proses perkuliahan berlangsung, tetapi juga nampak di luar kelas menunggu pergantian waktu kuliah. Mereka dapat berdiskusi dan mengerjakan tugas bersama di gazebo- gazebo kampus, atau di Café Ibu bercengkerama bersama sekalian makan siang. Di perpustakaan sebagai tempat untuk mengerjakan tugas, mencari literature kuliah ataupun untuk membaca buku. Pada saat Ujian akhir Semester di kampus sangat ramai jika di bandingkan dengan hari - hari biasa. Hal tersebut disebabkan mahasiswa yang biasanya tidak aktif kuliah hadir di kampus.

Mereka menyadari sebagai calon guru yang professional harus mampu menjadi teladan bagi peserta didiknya kelak. Untuk itu pada saat menempuh pendidikan calon guru harus dapat menumbuhkan nilai - nilai karakter kebangsaan dan multikulturalis, agar tidak terjadi disintegrasi bangsa Oleh karena bidang pendidikan merupakan sarana yang efektif dan efisien dalam transfer pengetahuan dan nilai budaya. Melalui interaksi antar mahasiswa di kampus dapat belajar bagaimana saling menghargai, saling gotong royong atau kerjasama, bertanggung jawab, disiplin dan kesetiakawanan sosial.

\section{Kegiatan Mahasiswa Program Studi Pendidikan Sejarah dan Sosiologi Di Luar Kampus}

Kegiatan mahasiswa Program Studi Pendidikan Sejarah dan Sosiologi di luar kampus dilatar belakangi oleh keinginan mereka untuk mengembangkan jiwa kepemimpinan melalui berorganisasi. Akan tetapi dari pihak kampus tidak dapat mewadahi keinginan tersebut. Pihak kampus hanya mewadahi kegiatan mahasiswa dalam organisasi BEM saja, sedangkan di tingkat Fakultas maupun Program Studi tidak ada. Setiap program Studi memiliki Karakteristik keilmuan yang berbeda - beda sehingga kebutuhan dan kepentingannya juga berbeda, seharusnya ada organisasi mahasiswa yang mampu mengakomodir keinginan mereka.

Komunitas di luar kampus yang dibentuk oleh mahasiswa Program Studi Pendidikan Sejarah dan Sosologi ada dua yaitu : Komunitas Sejarah dan Fotografi Sahitya (KSF Sahitya) dan Komunitas Pecinta Sejarah dan Budaya ( Kopi Suda). Dua komunitas 
tersebut dibedakan keanggotannya berdasarkan tahun masuk. Untuk KSF Sahitya diperuntukkan bagi mahasiswa angkatan 2014, Sedangkan Kopi Suda diperuntukkan bagi mahasiswa angkatan 2013. Anggotanya juga untuk mahasiswa sejarah dan sosiologi IKIP Budi Utomo Malang, tidak ada mahasiswa dari luar kampus.

Kegiatan- kegiatan yang dilakukan dalam komunitas tersebut berupa Field Trip dan penelitian ke situs-situs sejarah, Fotografi, Kewirausahaan,Out Bond dan Bakti Sosial. Rencana kerja dalam komunitas tersebut berdasarkan hobby dan minat mahasiswa sehingga bersifat isendental.

\section{PEMBAHASAN}

\section{Peranan Pendidikan Multikultural Dalam Meningkatkan Kesadaran Berbangsa dan Bernegara}

Pendidikan multikultural merupakan pendidikan yang menekankan untuk dapat saling menghargai keanekaragaman budaya. Setiap mahasiswa diharapkan dapat mengembangkan sikap empati dan saling mencintai adanya perbedaan suku, bahasa, budaya dan agama. Dengam demikian akan menghambat munculnya disintegrasi bangasam

Pendidikan Multikultural memiliki peranan yang cukup besar dalam menghadapi isu nasional dewasa ini yaitu isu SARA (Suku, Agama dan antar golongan). Mengigat bangsa kita merupakan bangsa yang majemuk yang memiliki keanekaragaman yang tinggi dilihat dari suku, agama, ras, bahasa dan budaya, maka sangat mudah menjadi sasaran isu SARA ( Suku, Agama, Ras antar Golongan) tersebut. Perkembangan teknologi dan komunikasi pada era globalisasi saat ini sangat muda dalam menghembuskan isu SARA (Suku, Agama, Ras antar Golongan) melalui Internet dan jejaring sosial. Sebagian besar masyarakat Indonesia telah sadar akan kebutuhan teknologi dan komunikasi, maka jejaring sosial dijadikan sarana yang paling mudah dalam mengakses informasi, seperti: Facebook, WA, Twiter, Line, Part, Yahoo Messegger, Google Messeger dan Instagram. Melalui Media sosial tersebut isu SARA (Suku, Agama, Ras antar Golongan) dapat dipublikasikan baik dengan ajakan melalui video dan foto, atau menyebarkan informasi yang mengundang disintegrasi seperti : bahaya ISIS yang telah mengancam keutuhan masyarakat Dunia.

Era globalisasi merupakan masa tanpa adanya sekat pembantas antar bagian masyarakat sehingga bersifat menyeluruh. Hal ini ditandai dengan perkembangan Ilmu Pengetahuan dan Teknologi, sehingga masyarakat dapat mudah untuk mengakses informasi apapun. Mobilitas dan kinerja masyarakat juga berkembang sangat cepat, sehingga apabila tidak dapat mengikuti perkembangan ilmu pengetahuan dan teknologi akan tertinggal dan tidak mampu bertahan hidup. Untuk itu masyarakat Indonesia dalam menghadapi Era Globalisasi harus memperkuat nilai - nilai persatuan dan kesatuan bangsa agar tidak mudah diintervensi oleh bangsa lain.

Permasalahan bangsa Indonesia dewasa ini yang paling berat adalah isu SARA (Suku, Agama, Ras antar Golongan) yang menjadi isu nasional. Peristiwa - peristiwa yang terjadi seperti pengeboman di gereja, masjid, mall dan perkeantoran, Tawuran antar sekolah, Konflik antar etnis, Tawuran antar mahasiswa, Penjarahan geng motor, Konflik antar suku, merupakan bagian dari isu SARA (Suku, Agama, Ras antar Golongan). Hal tersebut disebabkan karena tidak adanya jiwa persatuan dan kesatuan serta hilangya sikap toleransi atau saling menghargai antara satu dengan yang lain.Oleh karena itu sebagai generasi muda harus tanggap dan peduli terhadap permasalahan- permasalahan sosial tersebut, khususnya mahasiswa sebagai motor penggerak perubahan bangsa. 
Pendidikan multikultural memiliki peranan penting dalam menumbuhkan karakter kebangsaan, karena dengan mempelajari pendidikan multikultral para mahasiswa dapat memahami dan mengenal keanekaragaman Budaya, bahasa, suku, agama dan ras yang dimiliki oleh bangsa Indonesia. Dengan demikian mereka dapat mengembangkan sikap toleransi dan mengakui keberadaan masing masing mahasiswa dengan perbedaan yang mereka miliki. Perbedaan - perbedaan yang mereka miliki justru dapat saling melengkapi kekurangan masing - masing dan dapat bersatu padu serta bahu membahu membangun Indonesia melalui bidang pendidikan.

Pendidikan multikultural juga dapat menumbuhkan karakter kebangsaan, sebab dapat membantu mahasiswa untuk merasakan “ keindonesiaan", Hal tersebut dapat dilihat dalam mahasiswa berinteraksi dengan berbagai mahasiswa yang memiliki perbedaan budaya, suku, agama, ras dan etnis secara tidak langsung mereka dapat saling mengenal dan mempelajari budaya masing - masing daerah, sehingga dapat menumbuhkan semangat nasionalisme.

Pendidikan multikultural dapat diterapkan dengan mudah dalam dunia pendidikan khususnya pendidikan formal. Hal tersebut disebabkan karena instansi pendidikan memiliki peran untuk menstransfer ilmu pengetahuan dan nilai- nilai budaya. Oleh karena itu mahasiswa Program Studi Pendidikan Sejarah dan Sosiologi IKIP Budi Utomo Malang merupakan calon guru atau pendidik, sebaiknya di bekali dengan pendidikan multikultural. Seorang guru sejarah dan sosiologi harus dapat membentuk peserta didiknya memiliki karakter kebangsaan, sehingga di dalam mengajar tidak hanya menitikberatkan pada aspek kognitif tetapi juga afektif dan psikomotorik. Guru sejarah tidak hanya memberikan fakta - fakta kering saja kepada peserta didikya tetapi harus dapat membentuk karakter kebangsaan dalam diri siswanya.

Untuk itu pendidikan multikultural sangat penting diberikan bagi mahasiswa pendidikan sejarah dan sosiologi yang merupakan calon guru. Hal tersebut dikarenakan pendidikan multikultural dapat membekali mahasiswa bagaimana dalam berinteraksi dengan siswa maupun antar guru, menumbuhkan karakter kebangsaan dan multikultural bagi peserta didik, melestarikan budaya bangsa, mengembangkan sikap empati dan toleransi, mengembangkan sikap gotong royong atau bekerjasama, Dengam demikian seorang guru sejarah dan sosiologi dapat menjadi teladan bagi peserta didiknya khususnya dalam mengembangkan karakter kebangsaan dan multikultur.

\section{Cara Mengembangkan Pendidikan} Multikultural Dalam Meningkatkan Kesadaran Berbangsa dan Bernegara

Cara mengembangkan pendidikan multikultural tidak hanya dalam pendidikan formal saja, akan tetapi bisa juga melalului pendidikan non formal yang didirikan oleh LSM (Lembaga Sosial Masyarakat). Di kota Malang banyak sekali LSM dan komunitas yang dibentuk oleh mahasiswa, dosen maupun aktivis yang berbasis multikultural. Bentuk kegiatan mereka juga beragam yaitu : Bimbel, Pelatihan, Pendampingan, Baksos, Diskusi, Seminar, Penerbitan buku atau majalah, Out Bond, Pelatihan ketrampilan, Bantuan beasiswa atau dana pendidikan. Kegiatan kegiatan tersebut biasanya terkoordinasi dengan baik dan memiliki rencana yang temporal. Banyak tokoh - tokoh agama, tokoh masyarkat, sastrawan, budayawan, politikus, anggota dari berbagai profesi bergabung bersama untuk mewujudkan visi dan misi komunitas mereka.

Pendidikan multikultural dalam pendidikan formal dapat dikembangkan melalui kurikulum terintegrasi yaitu 
pendidikan multikultural dalam penyampaiannya dapat dimasukan dalam berbagai mata kuliah atau mata pelajaran sesuai dengan karakteristik masing - masing bidang ilmu. Oleh karena itu dalam penyampaiannya dikemas sesuai dengan kajian bidang ilmunya, jadi tidak lagi ada anggapan bahwa yang berhak untuk menyampaikan pendidikan multikultural adalah mereka yang dari rumpun ilmu sosial, akan tetapi dari rumpun ilmu alam juga dapat menyampaikan.

Di dalam Kurikulum Perguruan Tinggi pendidikan multikultural dapat diintegrasikan dengan kelompok mata kuliah lain seperti MKPK (Mata Kuliah Pengembangan Kepribadian), MKK ( Mata Kuliah Keilmuan dan Ketrampilan), MBB (Mata kuliah berkehidupan kebangsaan). Dengan demikian cara penguatan pendidikan multikultural di Perguruan tinggi dapat dilakukan dengan konsistensi pengambil Kebijakan Perguruan Tinggi untuk mewajibkan pendidikan multikultural dimasukan dalam kurikulum Program Studi. Di samping itu juga dalam penyampaian materi pendidikan multikultural tidak hanya bersifat teoritis dan disampaikan secara lisan, tetapi harus sampai pada tataran penerapan yang disertai dengan contoh atau bukti kongkret.

Bentuk pengembangan pendidikan multikultural yang lainnya yaitu melalui bazaar dan pentas seni serta bakti sosial. Mahasiswa Program studi pendidikan sejarah dan soiologi memiliki keanekaragaman budaya yang tinggi, maka melalui kegiatan pentas seni mereka dapat menunjukkan tarian atau seni music yang khas dari masing - masing daerah. Dengan demikian dapat saling mengenal budaya masing - masing daerah yang dapat meningkatkan khasanah budaya. Sedangkan melalui kegiatan bazaar mahasiswa dapat menjual makanan dan minuman maupun kerajinan tangan khas daerah masing masing, sehingga dapat mengenal dan mempelajari budaya lain.
Di samping itu kegiatan luar kampus dapat digunakan untuk saling mengenal budaya masing - masing daerah, seperti kegiatan : lawatan sejarah dan sinau sejarah ke beberapa situs sejarah dapat menambah khasanah budaya lokal. Hasil kunjungan ke beberapa situs sejarah dapat dilaporkan dan didiskusikan secara bersama dalam forum seminar. Hal tersebut dapat menumbuhkan jiwa kritis dan menciptakan suasana akademik di kalangan mahasiswa.

Pada era globalisasi dengan kemudahan mengakses berbagai informasi menyebabkan banyak mahasiswa memiliki kecenderungan malas untuk membaca buku dan lebih tergantung pada internet dalam mencari sumber pustaka, bahkan dalam membuat tugas makalah hanya mengcopy paste dari artikel artikel di internet. Untuk itu kegiatan filed trip atau study tour juga dapat membantu mahasiswa mengembangkan rasa ingin tahu yang tinggi dan mencari sumber informasi yang akurat dan terpercaya, serta belajar menulis karya ilmiah berupa proposal penelitian dan makalah. Di samping itu juga belajar bekerjasama dan saling menghargai antar mahasiswa satu dengan yang lain.

\section{Hambatan Yang Dihadapi Dalam Mengembangkan Pendidikan Multikultural Untuk Meningkatkan Kesadaran Berbangsa dan Bernegara}

Pengembangan Pendidikan Multikultural di Program Studi Pendidikan Sejarah Sosiologi IKIP Budi Utomo Malang masih belum dapat dioptimalkan. Hal tersebut disebabkan kurang sosialisasi dari pihak kampus di tingkat fakultas sampai Program Studi, padahal pendidikan multikultural telah menjadi matakuliah wajib yang diberikan di semua program studi berdasarkan sisdiknas Perguruan Tinggi tahun 2012. Oleh karena itu pemahaman mahasiswa akan pentingnya pendidikan multikultural belum dapat diketahui oleh semua mahasiswa, Mereka yang 
paham tentang pendidikan multikultural hanya sebagian yang sering mengakses informasi informasi di internet atau surat kabar.

Hambatan lainya yang ditemukan dalam pengembangan pendidikan multikultural yaitu kesadaran mahasiswa untuk memiliki keakraban dengan mahasiswa lain yang berbeda masih kurang. Hal ini di sebabkan karena masing - masing mahasiswa tidak saling mengenal satu dengan yang lain. Oleh karena itu seharusnya Program Studi pendidikan Sejarah dan Sosiologi mengadakan kegiatan keakraban bagi mahasiswa baru, sehingga mereka dapat saling mengenal satu dengan yang lain serta mengenal masing masing dosen. Di samping itu kegiatan keakraban ini dapat mempererat persaudaraan dan ikatan kekeluargaan, sehingga mereka dapat meiliki kesadaran sebagai bagian dari satu keluarga. Kegiatan keakraban juga dapat digunakan sebagai sarana untuk mensosialisaikan rencana program studi, kebijakan lembaga, kegiatan - kegiatan akademik di kampus, strategi dalam megikuti perkuliahan, informasi - informasi akademik lainnya.

Selama ini informasi akademik hanya di sampaikan melalui media sosial facebook yang telah dibuat group berdasarkan tahun masuk, tetapi yang menyerap informasi tidak semuay disebabkan karena tidak semua mahasiswa memiliki akun facebook dan Handpon yang berbasis android, yang dapat mengakses informasi setiap waktu. Akibatnya sosialisasi akademik tidak dapat tersampaikan secara optimal, contohnya : masih banyak mahasiswa yang terlambat melakukan heregistrasi, mebedakan KRS dan KHS juga tidak bisa, Memprogram mata kuliah juga tidak bisa.

Ada beberapa mahasiswa di Program Studi Pendidikan Sejarah dan Sosiologi masih mempertahankan sifat dan karakter asli daerahnya sendiri, sehingga sulit untuk beradaptasi maupun berbaur dengan teman lain yang memiliki perbedaan budaya.
Mahasiswa - mahasiswa yang sulit untuk berbaur dan berinteraksi dengan mahasiswa yang berbeda suku dan budaya akan menghambat dalam pengembangan pendidikan multikultural. Mereka mengalami kesulitan dalam berdapatasi maupun berinteraksi, akibatnya tidak diterima dalam pergaulan di dalam kelas maupun di luar kelas.

Hambatan dalam pengembangan pendidikan multikultural lainya adalah dari pihak kampus kurang memberi ruang untuk mahasiswa berlatih jiwa kepemimpinan dan melatih sikap demokratis. Pihak kampus hanya mewadahi aspirasi mahasiswa dalam organisasi BEM (badan Eksekutif Mahasiswa), sedangkan di tingkat Fakultas dan Program Studi tidak tersedia. Setiap fakultas dan Program studi memiliki kebutuhan dan permasalahan yang berbeda-beda, seharusnya di tingkat fakultas dan Program Studi dibentuk organisasi dalam kampus yang dapat menampung aspirasi semua mahasiswa. Di samping itu melalui organisasi tersebut meraka dapat belajar kepemimpinan, bekerjasama, demokrasi, toleransi, solidaritas, disiplin dan tanggung jawab. Organisasi juga mengajarkan mereka membuat perencanaan kegiatan, membuat program kerja, menyusun proposal, mengelola keuangan, ketrampilan mengembangkan organisasi.

Untuk itu himpunan mahasiswa di tingkat fakultas dan program studi sangat penting perannya dalam mengembangkan pendidikan multikultural dalam mahasiswa Program Studi Sejarah dan Sosiologi. Hal tersebut dikarenakan mereka dapat menjalin interaksi yang erat, dapat saling mengenal satu dengan yang lain, sehingga meningkatkan keakraban, dapat mempelajari dan mengenal budaya lain sehingga mampu beradaptasi dengan lingkungan setempat.

Himpunan mahasiswa juga dapat digunakan sebagai kepanjangan tangan Fakultas atau Program Studi dalam mensosialisasikan kebijakannya. Di samping 
itu juga dapat menampung permasalahan mahasiswa yang dapat disampaikan ke Ketua Program Studi dan Dekan. Dengan demikian Dekan dan Ketua program Studi tidak mengalami kesulitan dalam menggali permasalahan maupun kebutuhan mahasiswa di tingkat fakultas dan program studi

\section{KESIMPULAN DAN SARAN}

Pendidikan multikultural memiliki peranan penting dalam menumbuh kembangkan karakter kebangsaan, karena dengan mempelajari pendidikan multikultural para mahasiswa dapat memahami dan mengenal keanekaragaman Budaya, bahasa, suku, agama dan ras yang dimiliki oleh bangsa Indonesia. Dengan demikian mereka dapat mengembangkan sikap toleransi dan mengakui keberadaan masing - masing mahasiswa dengan perbedaan yang mereka miliki. Mahasiswa juga dapat beradaptasi dengan lingkungan sekitar serta berinteraksi di dalam kelas maupun di luar kelas.

Pengembangan pendidikan multikultural di Perguruan Tinggi dapat diintegrasikan dengan kelompok mata kuliah lain seperti MKPK (Mata Kuliah Pengembangan Kepribadian), MKK (Mata Kuliah Keilmuan dan Ketrampilan), MBB (Mata kuliah berkehidupan kebangsaan). Di samping itu juga dalam penyampaian materi pendidikan multikultural tidak hanya bersifat teoritis dan disampaikan secara lisan, tetapi harus sampai pada tataran penerapan yang disertai dengan contoh atau bukti kongkret. Sedangkan Pengembangan pendidikan multikultral lainnya dapat melalui kegiatan - kegiatan bazaar budaya, pentas seni dan bakti sosial.

Hambatan dalam pengembangan pendidikan multikultural di Program Studi Pendidikan Sejarah dan Sosiologi adalah kurangnya sosialisasi dari Program Studi akan pentingnya pendidikan multikultral, masih ada mahasiswa yang membawa sifat karakter dari asal daerah sehingga tidak dapat berbaur dan beradaptasi, Fakultas maupun Program Studi tidak memiliki himpunan mahasiswa yag dapat dijadikan sebagai wadah untuk dapat mengembangkan kegiatan mahasiswa yang berbasis multikultur.

Untuk itu pengembangan Pendidikan Multikultural di Perguruan Tinggi, sebaiknya memasukkan pendidikan multikultural dalam kurikulum program studi, sehingga terintegrasi dengan kelompok - kelompok mata kuliah keahlian dan ketrampilan prodi. Di samping itu mahasiswa di berikan ruang dalam berkreatifitas mengadakan kegiatan - kegiatan yang berbasis multikultural. Dosen

dalam menyampaikan materi perkuliahan dapat mengembangkan nilai- nilai karakter kebangsaan dan multikultural yang tidak hanya bersifat teoritis, tetapi juga sampai ke penerapan dalam kehidupan sehari-hari mahasiswa. Sedangkan sebagai mahasiswa sebaiknya bersikap kritis dan cerdas dalam menyikapi isu - isu SARA ( suku, Agama, Ras dan Antar Golongan), artinya tidak mudah terprovokasi terhadap isu-isu tersebut.

\section{DAFTAR RUJUKAN}

Yakin, A. 2005. Pendidikan Multikultural. Yogyakarta : Pilar Media

LiLiweri, A. 2005 . Prasangka dan Konflik: Komunikasi Lintas Budaya Masyarakat Multikultur. Yogyakarta : LKis

Azra, A. 2003. Pendidikan Multikultural, Membangun Kembali Bhineka Tunggal Ika Dalam Tsaqofah, -Menggagas. Pendidikan Multikultural",Vol 1,Nomor 2, Tahun 2003

Mahfud, C. 2006. Pendidikan Multikultural.Yogyakarta : Pustaka Pelajar

Sparingga, D. T. 2003. Multikulturalisme dalam Multiprespektif di Indonesia. Surabaya : Forum Rektor Simpul Jawa Timur Universitas Surabaya. 
Hamid, F. A. 1999. Pendidikan Multikultural dalam Konteks Pengembangan serta Implementasi Kurikulum Sekolah di Indonesia, Dalam Konvensi Nasional Pendidikan Indonesia II: kurikulum untuk Abad ke 21, Jakarta : Gramedia.

Tilaar, H.A.R.. 2002. Perubahan Sosial Dan Pendidikan : Pengantar Pedagogik Transformatif untuk Indonesia. Jakarta : Grasindo

Sutopo, H.B.. 2006. Penelitian Kualitatif.Surakarta : UNS Press

Buchori, M. Pendidikan Multikultural, dalam Kompas Edisi 4 Maret 2007

Wiriaatmadja, R. 2004. Multikultural Perspektive in Teaching History to The Chinese Indonesian Students. Dalam Historia No 9 Volume V. Bandung : Pendidikan Sejarah UPI

Soebijantoro, 2011. Peran Pendidikan Sejarah Dalam Pengebangan Pembelajaran Multikultur di LPTK, Dalam Agastya Jurnal pendidikan dan pembelajaran sejarah, Vo01,No1,Hal 20-24.

Suryaman. 2010. Analisis Kepemimpinan Multikultural di Sekolah Menegah dalam Upaya Mencegah Fenomena Gegar Budaya : Konteks Indonesia, Dalam Sosio Humanika Jurnal Pendidikan Sains Sosial dan Kemanusiaan, Vol 3, No. 1, Hal $112-113$

Kartodirdjo, S. .2000. Revitalisasi Bhineka Tunggal Ika Tan Hana Mangrwa dalam Rangka Menuju Indonesia Baru, Maklah disaijkan dalam Sarasehan Membangun Wawasan Kebangsaan Melalui Revitalisasi Budaya yang diselenggarakan oleh Keraton Kasunanan, Pura Mangkunegaran, PII dan HKMN Suryasumirat, di Surakarta pada tanggal 5 Agustus 2000.

Hartono, Y. 2011. Pembelajaran Sejarah Yang Multikultural Untuk Membangun Karakter Bangsa, Dalam Agastya Jurnal pendidikan dan pembelajaran sejarah,

Vol 01,No1,Hal

33-34 